\title{
Public Satisfaction Index of Religious Education Services in Schools in West Java
}

\author{
Saimroh, Mulyana, Abdul Basid, Sumarsih Anwar, Juju Saepudin, Neneng Habibah, \\ Nursalamah Siagian, Ibnu Salman, and Nur Alia \\ \{saimroh@gmail.com, yana.litbangjkt@gmail.com, abd.basid19@gmail.com\} \\ Office of Religious Research and Development Ministry of Religious Affairs Jakarta, \\ Jalan Rawa Kuning No. 6, Pulogebang, Cakung, East Jakarta, Indonesia 13950
}

\begin{abstract}
In this paper, we present the results of a survey that measured the level of public satisfaction towards religious education services in schools. Dimensions of public services measured included: requirements, procedures or provisions, time of completion, costs, service products, competencies and behaviors of public service officers, complaint handling, and facilities. 400 students of senior high schools in West Java Province, along with 394 parents, were randomly selected as respondents for this survey using a multistage random sampling technique. The survey results found that the levels of student and parent satisfaction respectively achieved 77.70 and 73.32 on the scale $25-100$. The service product obtained the highest level of student and parent satisfaction, while the aspects of service costs and facilities got the lowest scores.
\end{abstract}

Keywords: Satisfaction Index, Religious Education Service, Public Satisfaction

\section{Introduction}

Indonesian are known as religious people. Therefore, public demands for religious education services are increasingly high. Law Number 20 Year 2003 article 12 paragraph 1 states that government must provide religious education in accordance with the religion adopted by students and taught by educators of the same religion [1].

In reality, religious education services in several schools have not fulfilled the mandate of the law. Most of these schools are schools that are already affiliated with certain religions. [2] found that several Catholic schools in Blitar had not provided religious education services according to the religion of the students. Muzayanah's findings that Christian learning is joined with Catholicism and were taught by Catholic teachers at high schools in Bali [3]. Dominikus Wonosari High School which is a Catholic religious foundation, does not serve religious education in accordance with the religion of its students [4]. However, some schools were found to be able to provide religious education according to their religion, such as Muhammadiyah High School in Kupang [5], Catholic Soverdi High School [6] and several schools in Bogor, Denpasar, Manado, Ende, and Bekasi [7], [8].

Besides the problem of the adequacy of religious teachers in schools, the lack of religious learning facility also gives impact towards the process of teaching and learning of religious education in schools. As a result, religious education services in schools are less than optimal. A Survey of the Center for Research and Development of Religious and Religious Education, 
Ministry of Religion (2016) found an index of religious education services in schools in 32 provincial capitals in Indonesia of 0.81 . The index is measured by three indicators, namely: religious teachers, learning facilities and the teaching-learning process of religious education in high schools and vocational high schools. The study was conducted using the self-assessment method for principals, religious teachers and students [9].

Some of the studies above show that there is still a gap between expectations and the reality of religious education services in schools. To find out the extent of this gap, satisfaction surveys can be carried out [10], [11]. In the regulation of the minister of religion of the Republic of Indonesia number 16 of 2010 article (3) it is mentioned that religious education is the right of every student as a citizen [12]. For this reason, religious education is a public service. The government is responsible for providing quality religious education services.

Public service according to Law Number 25 Year 2009 is an activity or series of activities in the framework of meeting service needs in accordance with statutory regulations for every citizen and resident of goods, services, and or administrative services provided by public service providers [13] Meanwhile, [14] defines service as a way of serving, helping, preparing, managing, completing the needs or needs of individuals and groups. This understanding is in line with [15] that service is a process of need through other people's activities directly or an act that actively involves the recipient of service services. [16] defines public services as services needed by the community, not what the government wants. From these definitions, public services referred to in this study are all service activities carried out by public service providers in an effort to meet the needs of the community.

Religious education according to the regulation of the Minister of Religion of the Republic of Indonesia number 16 of 2010 is education that provides knowledge and shapes the attitudes, personalities, and skills of students in practicing their religious teachings, which is implemented at least through subjects in all lines, levels and types of education. Religious Education consists of: Islamic Religious Education, Catholic Religious Education, Christian Religious Education, Hindu Religious Education, Buddhist Religious Education and Confucius Religious Education. Religious education is formally organized by schools at the elementary and secondary education levels. Schools become organizations that are designed to be able to provide services and contribute to efforts to improve the quality of life of their students later [17].

This study intends to measure the extent of community satisfaction with education services in schools. The dimensions of religious education services refer to the Regulation of the Minister of Administrative Reform and Bureaucratic Reform of the Republic of Indonesia Number 14 of 2017 (PANRB Ministerial Regulation No. 14/2017). The regulation explained that public services consist of nine dimensions including: requirements, procedures or mechanisms, completion time, costs, service products, implementation competencies, implementing behavior, complaint handling, and service infrastructure [18]. For this reason, the research questions are: 1) what is the level of community satisfaction with religious education services in schools? 2) what are the factors that influence the level of community satisfaction in religious education services in schools? 


\section{Research method}

\subsection{Population and sampling}

This research uses a quantitative approach with a survey method. The population of this study was high school (high school) students and vocational high schoo in West Java province. Sampling technique being used is multi-stage random sampling. First sampling stage is choosing the district and city samples using Proportional to Size (PPS), second stage is done by taking a random sample of high school and vocational school based on strata status of public and private institutions, and finally in the third stage, 10 students were randomly drawn from selected schools, consisting of 5 male students and 5 female students. The survey analysis unit is the user of religious education services in schools that are restricted to second-year high school / vocational high school students. The number of high school / vocational students in the province of West Java refers to the Basic Education Data from the Ministry of Education and Culture of 1,707,166 students (http://dapo.dikdasmen.kemdikbud.go.id/sp). The sample calculation uses the Krejcie and Morgan formula with a margin of error of $5 \%$. The number of students as many as 400 people and 396 students' parents because 4 questionnaires did not return.

\subsection{Data collection instruments}

Research data were collected using questionnaire distributed to student and parents. Data was collected in October - November 2017 with a questionnaire technique in accordance to PermenPANRB 14/2017. The questionnaire consisted of nine dimensions of public service, which was measured by a Likert Scale of 1-4.

\section{Requirements}

Requirements that must be met in the maintenance of a type of service, both technical and administrative. Indicators of service requirements are religious requirements, educators, mandatory books, and places of worship.

\section{System and mechanism (procedures)}

Service procedures are standardized for service providers and recipients, thus including complaints procedure. Service procedures are consisted of planning, implementation to evaluation of teaching and learning of religious education in schools, both intra and extracurricular.

\section{Time spent}

Time needed to complete the entire service process of each type of religious education service both in intra-curricular and extracurricular activities.

Fees or rates

The fee charged to the service recipient in managing and/or obtaining service from the organizer is determined based on agreement between the service organizer and the community. Costs or fees for religious education services are including the costs of activities and the costs of educational facilities. 
Product specifications

The results of services provided and accepted by clients are in accordance with the provisions set before. The product of religious education are in the form of students' knowledge, attitudes, personalities, and skills in practicing their religious teachings.

\section{Officer competence}

Ability that must be possessed by the officer which includes: competence in knowledge, expertise, skills and experience.

\section{Officer behavior}

The attitude of officers in providing services which includes: discipline, physical appearance, attention or empathy, and keeping promises to serve clients.

Handling complaints, suggestions and input

The procedures for the handling of complaints and follow-up, which includes: means of complaints, accuracy and speed of complaints.

\section{Infrastructure}

Infrastructure of religious education services includes: learning resources, classrooms, facilities for worship, and religious labs.

\subsection{Instrument validation}

The questionnaire consisted of two, namely: a questionnaire for students which was elaborated in 64 items and a questionnaire for parents of students which included 46 questions. The student questionnaire trial was conducted on 15211 th grade students at SMA / SMK. Whereas the parents' questionnaire test was given to 94 parents of 11 th grade students in SMA 1. Validity test uses Pearson Product Moment correlation analysis, while the reliability analysis uses Cronbach's Alpha coefficient. Validity analysis produced 6 invalid items and 58 valid items. So the questionnaire in the study used 52 valid items. The results of the reliability analysis resulting an Alpha Cronbach coefficient of 0.928. While the validity test of students' questionnaires obtained 3 items invalid and 43 items valid with Cronbach's Alpha coefficient of 0.949 .

\subsection{Data analysis technique}

Data analysis was performed using descriptive and multivariate statistical methods. Descriptive analysis uses Public satisfaction index (PSI). Multivariate analysis uses One Way Anova to test differences in PSI according to the characteristics of the respondents. PSI calculation refers to PermenPANRB 14/2017 measured average weight and PSI is calculated by the following formula:

$$
\text { Weightedaverageweight }=\frac{\text { numberofweights }}{\text { numberofdimensionsi }}=\frac{1}{9}=0,111
$$


PSI value is converted to percentage form to ease interpretation. Furthermore, it is broken into four categories of service quality as follows:

$$
P S I=\frac{\text { thetotalvalueofperceptionperelement }}{\text { totalelementsfilledin }} \text { xweighingvalue }
$$

Table 1. Converted Public Satisfaction Index (PSI) categorization.

\begin{tabular}{rcc}
\hline PSI Conversion & $\begin{array}{c}\text { Service } \\
\text { Quality }\end{array}$ & Category \\
\hline $25,00-64,99$ & D & Poor \\
$65,00-76,60$ & C & Fair \\
$76,61-88,30$ & B & Good \\
$88,31-100,00$ & A & Very Good \\
\hline
\end{tabular}

\section{Results and discussion}

\subsection{Demographics of respondents}

The research sample consisted of 400 students and 396 parents. The respondent's demographics explains the gender, type of school, school status, and religion of student, while the demographics of parents' includes: age, last education, and occupation. Student respondents came from $33 \%$ of high school students and $67 \%$ of vocational high school students. Based on institutional status, $67.5 \%$ of respondents came from private schools and $32.5 \%$ of respondents came from public schools. Male respondents were slightly higher at $50.75 \%$ and women at $49.25 \%$. Based on religion, $98.5 \%$ of respondents were Muslim, $1 \%$ were Catholic, and $0.25 \%$ were Buddhist.

Parents respondents who filled out the questionnaire consisted of students' fathers $(53.79 \%)$, and mothers $(46.21 \%)$. The age of parents is dominated by the age of $35-45$ years $(44.70 \%)$, age 46 - 55 years $(39.39 \%)$, age less than 35 years $(5.81 \%)$, age more than 55 years $(9,60$ percent), and did not answer $(0.51 \%)$. The educational aspects of parents varied in not graduating elementary school $(6.57 \%)$, elementary school $(31.82 \%)$, junior high school or equivalent $(20.20 \%)$, high school or equivalent $(27.53 \%)$, Diploma $(3.28 \%)$, Bachelor $(10.61 \%)$, and null answer $(0.25 \%)$. 


\subsection{Public Satisfaction Index (PSI)}

Public satisfaction is measured by index numbers. The higher the index number indicates the higher the satisfaction of the public as service user.

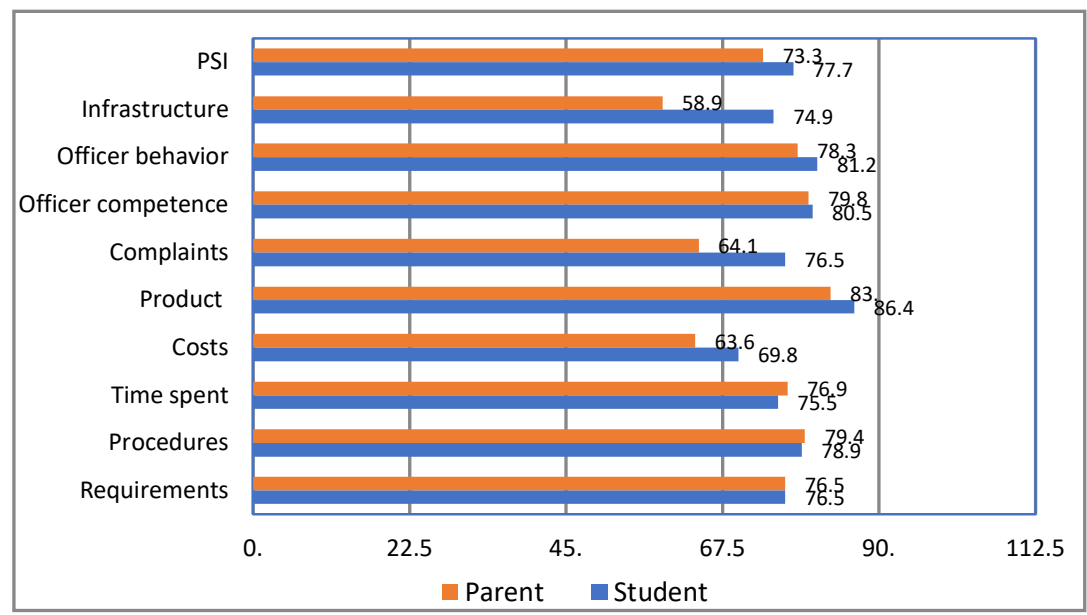

Fig 1. Public Satisfaction Index of religious education services for students and parents.

PSI on student respondents reached 77.70 or good category. While the PSIs of respondent parents is 73.32 or less good category. It means that there is a quite high gap from the perception of service satisfaction by students as primary customers and parents as secondary customers. Figure 1 shows that the highest gap of the nine dimensions of service is in the dimensions of religious education service facilities and infrastructure. Students as primary customers consider that the facilities and infrastructure of religious education services in schools are not good. While the parents of students as secondary customers also rated it as not good. The indicators that shows this condition are the number and condition of classrooms, religious education learning facilities and worship facilities provided by schools which are inadequate. Some schools do not even have special places of worship. They perform worship in classrooms with uncomfortable conditions. The number of worship facilities such as the Scriptures and clothing for worship in schools is very inadequate.

The biggest gap is also seen in the dimensions of the complaint. Students consider that the school is still not good in terms of complaints. Parents even considered that complaint of religious education services in schools were poorly managed. Indicators of this dimension includes: the means of complaints, speed and accuracy in handling complaints from clients. Most schools do not have media such as suggestion boxes for receiving complaints from the public. They sometimes submit complaints related to religious education in schools orally to the school principal or religious education teacher at the school.

The dimension that gets the lowest score out of the nine service dimensions is the cost or fees of religious education services which include the cost of carrying out religious activities and the purchase of religious facilities and infrastructure. Students assess the financial support or fees from schools and the government for religious activities and religious facilities and 
infrastructure in schools is still lacking. Some of the costs of religious education services are still borne by students or parents as recipients of services.

The product dimension gets the highest index of the nine service dimensions both in terms of students and parents response. Religious education products as stated in Ministry of Religion Regulation No. 16 of 2010 is to provide students with knowledge, attitudes, personality, and skills in practicing their religious teachings. The community feels that religious education in schools is good at providing religious knowledge and practicing their religious teachings. This is supported by the good behavior of religious education teachers and is an example for their students. Teacher competencies in religious education, including pedagogic, personality, social, and professional competencies, were assessed by students and parents as good (see figure 1)

\subsection{Indicator index in compiling satisfaction of religious education services}

Educational service consists of 9 dimensions which are broken down into several indicators. The dimensions of service satisfaction for students are based on 25 indicators, while the dimensions of service satisfaction for parents are explained in 23 indicators. The indicators of the PSI compiler indicators are illustrated by a radar chart. The longer the line, the higher the index number and vice versa. Figure 2 shows the indicators of learning resources and the complaint response has the shortest line which means that these two indicators get the lowest index. The community considers that learning resources such as religious education reference books in schools are inadequate. Textbooks from schools are supposed to be held by every student, but in fact, not every student has access since the insufficient amount of available

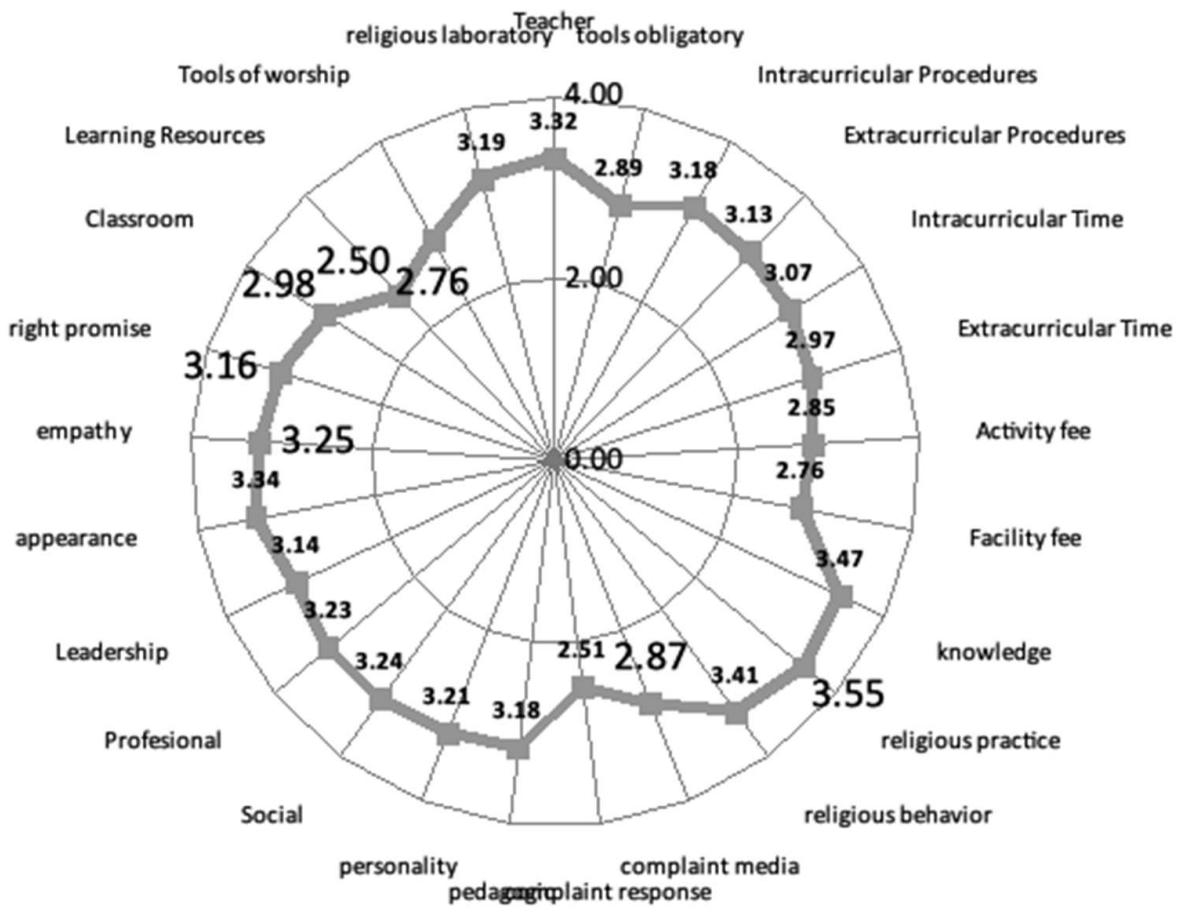

Fig 2. Indicator index compiling index of student satisfaction towards religious education services in schools. 
texbooks. Therefore, they have to read together or share one book for several students. Likewise, reading books with the theme of religious education are rarely found in school libraries. Most schools do not have media or facilities for filing complaints of religious education services, so the response to complaint handling is not fast and precise (see Fig. 2).

The highest index is obtained on the indicator of religious experience which is in a very good category. After experience, followed by the indicators of knowledge, religious behavior, and appearance of religious education teachers. This means that respondents were satisfied with religious education products in form of religious practice, knowledge, and religious behavior of students. Indicators of teacher behavior and competence as well as religious education get a high index which means that students are satisfied with the behavior and competence of religious education teachers in schools. Even indicators of the appearance of good looking religious teachers get the highest index on the dimensions of religious education behavior (see Fig. 3).

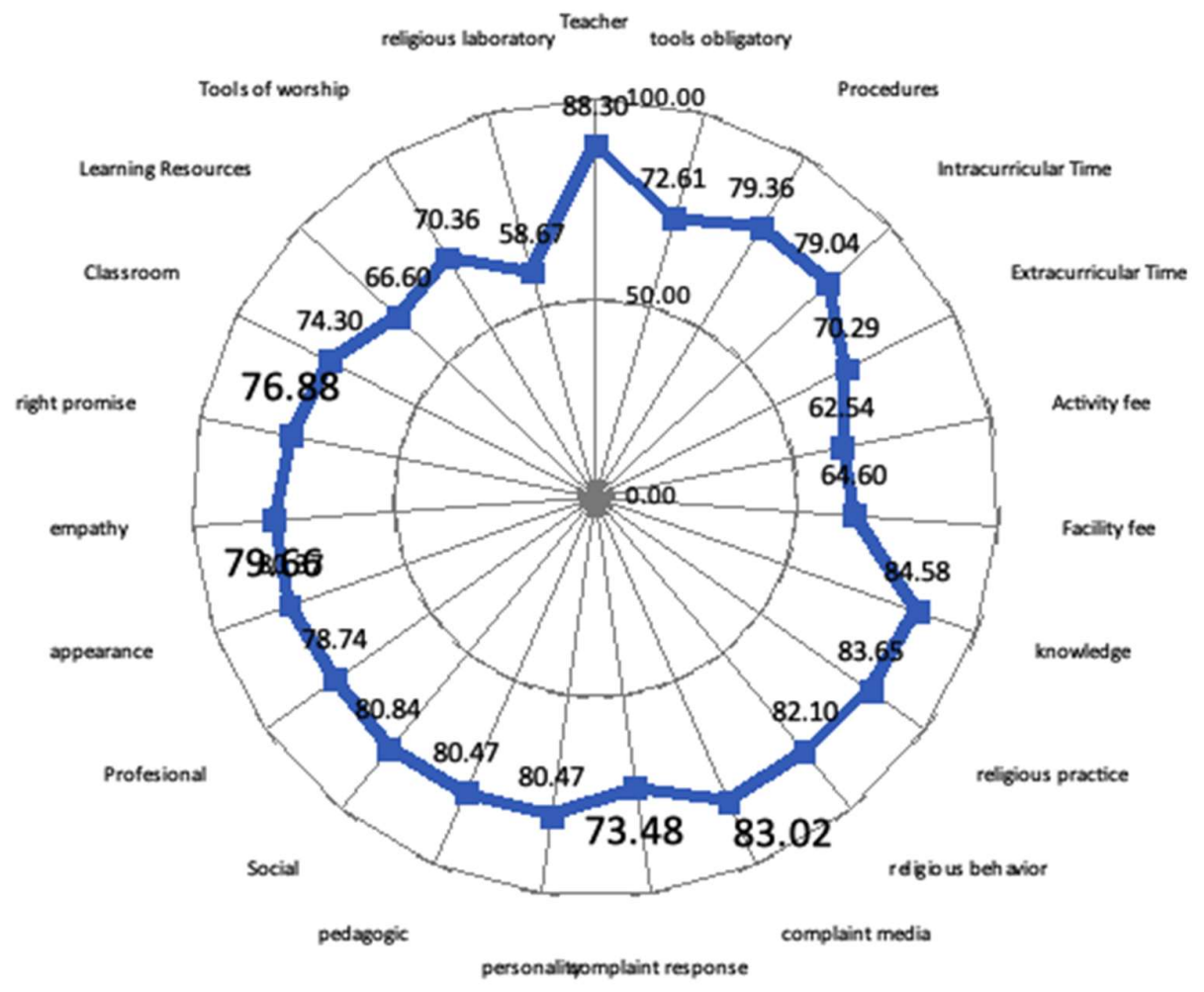

Fig. 3 Indicator index for compiling the parent satisfaction index to religious education services in schools 
The index of the PSI compiler indicators of parents is the lowest in the indicators of religious laboratories, activity funds and funds for religious facilities which are shown in bad category. The religious laboratory is a place of learning through the media of practice on religious and religious education. At the school level, usually it is in form of mushola or mosque which is used for places of worship and religious activities. Most schools do not have a mushola or mosque to conduct worship and religious activities. Fundings for religious activities and facilities in schools are also very low in schools. The highest indicator index is obtained on indicators of educators, knowledge, practice of religion, and religious behavior of students.

The findings on the parent PSI indicator index are consistent with the student satisfaction index. Religious education services in schools are good at providing outputs or products of religious education in the form of religious knowledge and aspects of practicing religious teachings. Religious teachers as the main figure in serving religious education, get a good index in terms of the behavior and competence of educators. 


\subsection{Index of satisfaction of religious education services by characteristics}

To test the differences in PSIs according to the characteristics of respondents, One Way Anova was used. Student PSI test results on religious education services in schools show significant on school status. The satisfaction index in public schools is higher than in private schools at the 5\% significance level. Whereas the characteristics of gender, religion, and type of school did not show any significant differences in PSIs (see Table 2).

Table 2. Difference test average student satisfaction index for religious education services according to characteristics.

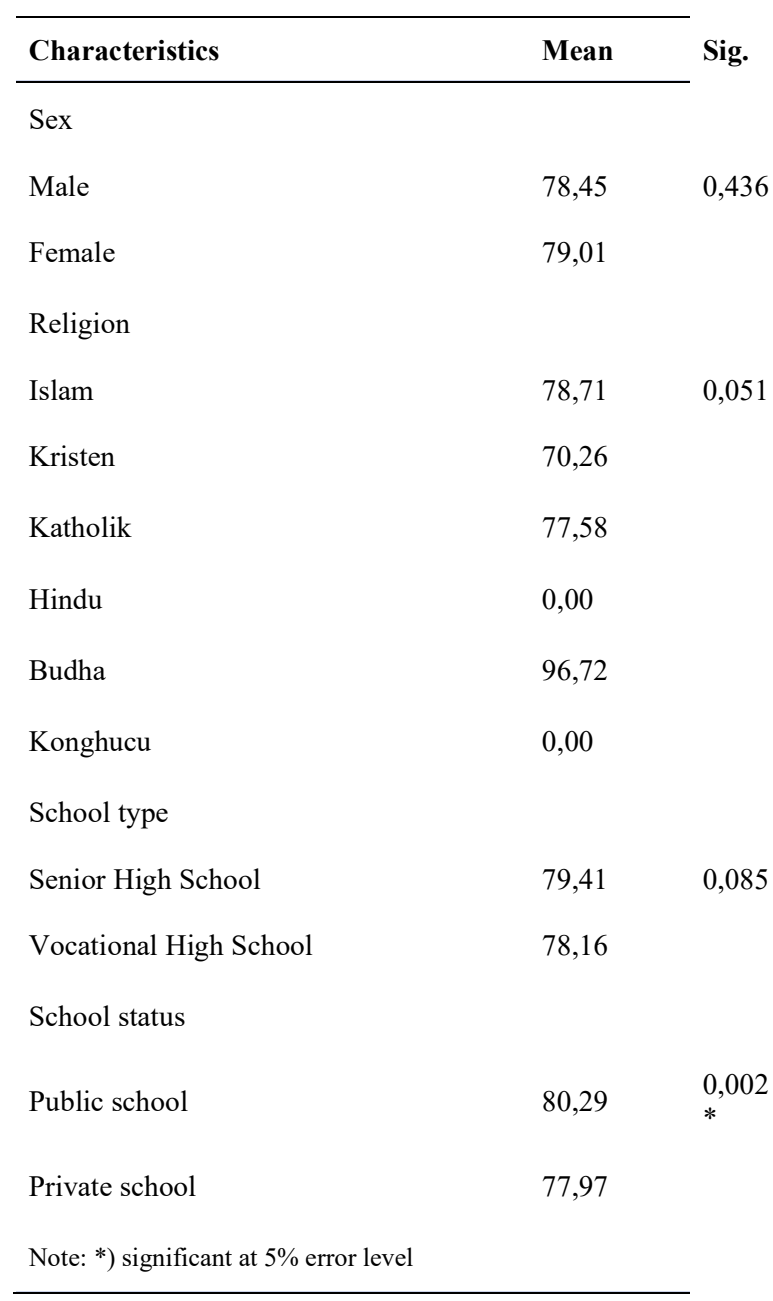


Table 3 shows that parent satisfaction index towards religious education services in schools in DKI Jakarta area are significantly the same in every characteristics being tested, such as school type, school status, age category, educational degree, and occupation.

Table 3. Difference tests in parents satisfaction index for religious education services according to characteristic.

\begin{tabular}{|c|c|c|}
\hline Characteristics & Mean & Sig. \\
\hline \multicolumn{3}{|l|}{ School type } \\
\hline General Senior High School & 77,13 & 0,720 \\
\hline Vocational Senior High School & 77,39 & \\
\hline \multicolumn{3}{|l|}{ School status } \\
\hline Public school & 78,16 & 0,099 \\
\hline Private school & 76,84 & \\
\hline \multicolumn{3}{|l|}{ Age } \\
\hline$<35$ years old & 78,32 & 0,261 \\
\hline 35 - 45 years old & 77,87 & \\
\hline 46 - 55 years old & 76,94 & \\
\hline$>55$ years old & 75,54 & \\
\hline \multicolumn{3}{|l|}{ Education } \\
\hline No school & 78,30 & 0,207 \\
\hline Pre-elementary school & 76,98 & \\
\hline Elementary school & 76,31 & \\
\hline Junior high school & 76,27 & \\
\hline Senior high school & 78,30 & \\
\hline Diploma & 77,24 & \\
\hline Bachelor & 79,23 & \\
\hline Postgraduate & 82,29 & \\
\hline
\end{tabular}




\section{Conclusions and recommendations}

This study concludes several things, first, the student PSI's towards religious education services in schools is in the good category. While the PSI of parents is in the poor category. Students and parents agree that the lowest index in the service of religious education in schools is the cost of religious education services. While the highest index is the product dimension or results received from religious education services. Second, the level of student satisfaction with religious education services is significantly influenced by school status. This means that the level of satisfaction with religious education services in public schools is higher than in private schools. While other factors such as student gender, religion, type of public and vocational school did not differ significantly in the level of community satisfaction with religious education services. But for parents of students, the level of satisfaction with religious education services is not influenced by factors of school type, school status, age, and level of education. This means that the characteristics of the students' parents do not influence their perception of satisfaction with religious education services in schools.

This research resulted in some recommendations, first, the Ministry of Religion needs to prioritize improvements or upgrades in the aspects of costs, complaints facilities, supporting infrastructure for religious education services in schools such as religious learning resources, worship facilities, and religious laboratories to improve the quality of religious education services in schools and to maintain the quality of the products or results of religious education in schools. Second, schools should provide media or means of complaints, suggestions, and input for the community to provide advice and input to schools.

Acknowledgment. This research was funded by the Jakarta Office of Religious Research and Development Ministry of Religious Affairs in 2017. We therefore would like to thank the Head of Jakarta Office of Religious Research and Development Ministry of Religious Affairs for supporting this research. We would like also to thank all those who have helped and facilitated this research.

*Main contributors 


\section{References}

[1] Indonesian Law Number 20 Year 2003 on the National Education System.

[2] Nurudin: Implementasi Kebijakan Pendidikan Agama di Sekolah-sekolah Katholik: Studi Kasus Kota Blitar Provinsi Jawa Timur [The Implementation of Religious Education Policy in Catholic Schools: A Case Study in Blitar City, East Java Province]. Edukasi, Vol. 11 No. 2, pp. 182-198 (2013). [3] Muzayanah, Umi: Pendidikan Agama dalam Bingkai Budaya Multikulturalis. Dalam Pendidikan Multikulturalis di Pulau Dewata [Religious Education in a Multiculturalist Frame. In Multiculturalist Education in the Island of God]. Mulyani Mudis Taruna (ed.). Arti Bumi Intaran, Yogyakarta (2015).

[4] Muzayanah, Umi: Implementasi Kebijakan Pendidikan Agama Bagi Siswa Minoritas pada SMA/SMK di Kabupaten Gunung Kidul [The Implementation of Religious Education of Minority Students in General Senior High School/Vocational Senior High School in Gunung Kidul Regency. Prosiding Bidang Pendidikan Agama dan Keagamaan, Vol. 4, pp. 143-162 (2017).

[5] Tholkhah, Imam: Pendidikan Toleransi Keagamaan: Studi Kasus SMA Muhammadiyah, Kupang Nusa Tenggara Barat [Religious Tolerance Education: A Case Study at Muhammadiyah Senior High School in Kupang, West Nusa Tenggara. Edukasi. Vol, 11 No. 2, pp. 168-181 (2013).

[6] Muawanah, Siti: Menggali Mutikulturalisme di Sekolah. Dalam Dalam Pendidikan Multikulturalis di Pulau Dewata [Exploring Multiculturalism in Schools. In Multiculturalist Education in the Island of God]. Mulyani Mudis Taruna (ed.). Arti Bumi Intaran, Yogyakarta (2015).

[7] Hayadin: Laporan Penelitian Layanan Pebelajaran Agama Sesuai Agama Siswa di Sekolah [Research Report on Religious Learning Services According to Students' Religions in Schools]. Paper presented at the Seminar on the Results of Religious Learning Services According to Students' Religions in Schools, September (2015).

[8] Balai Litbang Agama Semarang: Pelayanan Pendidikan Agama pada Sekolah Menengah (SMA/SMK) [Religious Education Services in General Senior High School/Vocational Senior High School]. Prosiding Bidang Pendidikan Agama dan Keagamaan, Vol. 4 (2017).

[9] Puslitbang Pendidikan Agama dan Keagamaan: Mendongkrak Indeks Layanan Pendidikan Agama di Sekolah [Increasing the Index of Religious Education Services in Schools]. In Annual Report on Religious Education (2017).

[10] Astuti, H.J.: Analisis Kepuasan Konsumen (Servqual Model dan Important Performance Analysis Model). Jurnal Media Ekonomi, Vol. 7, No. 1, pp. 1-20 (2007).

[11] Febriana, N.I.: Analisis Kualitas Pelayanan Bank terhadap Kepuasan Nasabah pada Bank Muamalat Indonesia Kantor Cabang Pembantu Tulungagung [An Analysis of the Quality of Banking Services to Customer Satisfaction at Bank Muamalat Indonesia, Tulungagung Sub-branch Office]. An-Nisbah: Jurnal Ekonomi Syariah. Vol. 3, No. 1, pp. 145-168 (2016). https://doi.org/10.21274/an.2016.3.1.145168.

[12] Indonesian Minister of Religious Affairs Regulation Number 16 Year 2010 on the Management of Religious Education in Schools.

[13] Indonesian Law Number 25 Year 2009 on Public Services.

[14] Sianipar, J.P.G: Manajemen Pelayanan Publik [Public Service Management]. Lembaga Administrasi Negara, Jakarta (1998).

[15] Warella, Y.: Administrasi Negara dan Kualitas Pelayanan Publik [Public Administration and the Quality of Public Services]. Inauguration Speech of the Associate Professor of Public Administration Science, Diponegoro University, Semarang (1997).

[16] Rana, Anoop SJB: The Sky Limit Public Services: New Approach. Liberal Time, FNS (1999).

[17] Kompri: Manajemen Pendidikan, Komponen-Komponen Elementer Kemajuan Sekolah [Education Management, Elementary Components of School Progress]. Ar Ruzz Media, Yogyakarta (2015).

[18] Indonesian Minister of State Apparatus Empowerment and Bureaucratic Reform Regulation Number 14 Year 2017 on the Guidelines for the Formulation of Public Satisfaction Survey by Public Service Unit. 